\title{
Evidence of perinatal transmission of Zika virus, French Polynesia, December 2013 and February 2014
}

M Besnard ${ }^{1}$, S Lastère $^{1}$, A Teissier ${ }^{2}$, V M Cao-Lormeau², D Musso (dmusso@ilm.pf)2

1. Centre hospitalier de Polynésie française, Hôpital du Taaone, Tahiti, French Polynesia

2. Institut Louis Malardé, Tahiti, French Polynesia

Besnard M, Lastère S, Teissier A, Cao-Lormeau VM, Musso D. Evidence of perinatal transmission of Zika virus, French Polynesia, December 2013 and February 2014 . Euro Surveill. 2014;19(13):pii=20751. Available online: http://www.eurosurveillance.org/ViewArticle.aspx?Articleld=20751

A Zika virus (ZIKAV) outbreak started in October 2013 in French Polynesia, South Pacific. We describe here the clinical and laboratory features of two mothers and their newborns who had ZIKAV infection as confirmed by ZIKAV RT-PCR performed on serum collected within four days post-delivery in date. The infants' infection most probably occurred by transplacental transmission or during delivery. Attention should be paid to ZIKAV-infected pregnant women and their newborns, as data on the impact on them are limited.

Since October 2013, French Polynesia has experienced the largest outbreak of Zika virus (ZIKAV) infection ever reported, with an estimate of 28,000 ZIKAV infections in early February 2014 (about $11 \%$ of the population) $[1,2]$. We report here evidence of perinatal transmission of ZIKAV in French Polynesia in December 2013 and February 2014.

\section{Clinical and laboratory description}

Case 1

In December 2013, a woman in her early 30 (Mother 1), who presented at hospital at 38 weeks' gestation, vaginally delivered a healthy newborn (Apgar score 10/10) (Newborn 1), who was immediately breastfed. The mother had a mild pruritic rash without fever that had started two days before delivery and lasted up to two days post-delivery (day 2). Clinical examination of the infant remained unremarkable from birth to five days after delivery, when the infant was discharged. The infant evolved favourably and the mother recovered favourably.

\section{Case 2}

In February 2014, a woman in her early 40 (Mother 2), who had been monitored for gestational diabetes and intrauterine growth restriction diagnosed during the second trimester of pregnancy, presented at hospital at 38 weeks' gestation for delivery. She underwent a caesarean section due to pregnancy complications. Her newborn (Newborn 2) had severe hypotrophy and Apgar score 8/9/9. Enteral nutrition with formula milk for premature newborns was started due to hypoglycaemia and breastfeeding was started, in addition, from the third day post-delivery (day 3). On day 3, the mother presented a mild fever $\left(37.5-38{ }^{\circ} \mathrm{C}\right)$ with pruritic rash and myalgia. The following day, after a threehour ultraviolet light session for neonatal jaundice, the newborn presented transiently an isolated diffuse rash. Both mother and infant evolved favourably.

\section{Laboratory features}

All available samples collected from Mother 1 and Newborn 1 until day 3 and from Mother 2 and Newborn 2 until day 13 were tested for ZIKAV and dengue virus (DENV). No other pathogens were tested for, given the co-circulation of DENV (serotypes 1 and 3) [3] and ZIKAV.

The test for ZIKAV was real-time reverse-transcription (RT) PCR using two primers/probe amplification sets specific for ZIKAV [4]: results were reported positive when the two amplifications occurred (threshold cycle less than 38.5). A standard curve using serial dilutions of known concentrations of a ZIKAV RNA synthetic transcript was included within the RT-PCR run to estimate the RNA loads. Both mothers and both newborns had ZIKAV infection confirmed by positive RT-PCR result on at least one serum sample.

Breast milk samples from both mothers were inoculated on Vero cells in order to detect replicative ZIKAV and were also tested by RT-PCR. The samples gave positive RT-PCR results, but no replicative ZIKAV particles were detected in cell culture. Blood cell counts were in the normal range, except for Newborn 2, who displayed a low platelet count from day $3\left(65 \times 10^{9} / \mathrm{mL}\right)$ to day $7\left(106 \times 10^{9} / \mathrm{mL}\right)\left(\right.$ norm: $\left.>150 \times 10^{9} / \mathrm{mL}\right)$ and an elevated level of total bilirubin on day $3(247 \mu \mathrm{mol} / \mathrm{L})$ (norm: $<200 \mu \mathrm{mol} / \mathrm{L}$ ); total protein and C-reactive protein levels were within the normal range.

All samples tested by ZIKAV RT-PCR were also tested for DENV using a multiplex RT-PCR [5]: all were negative. 


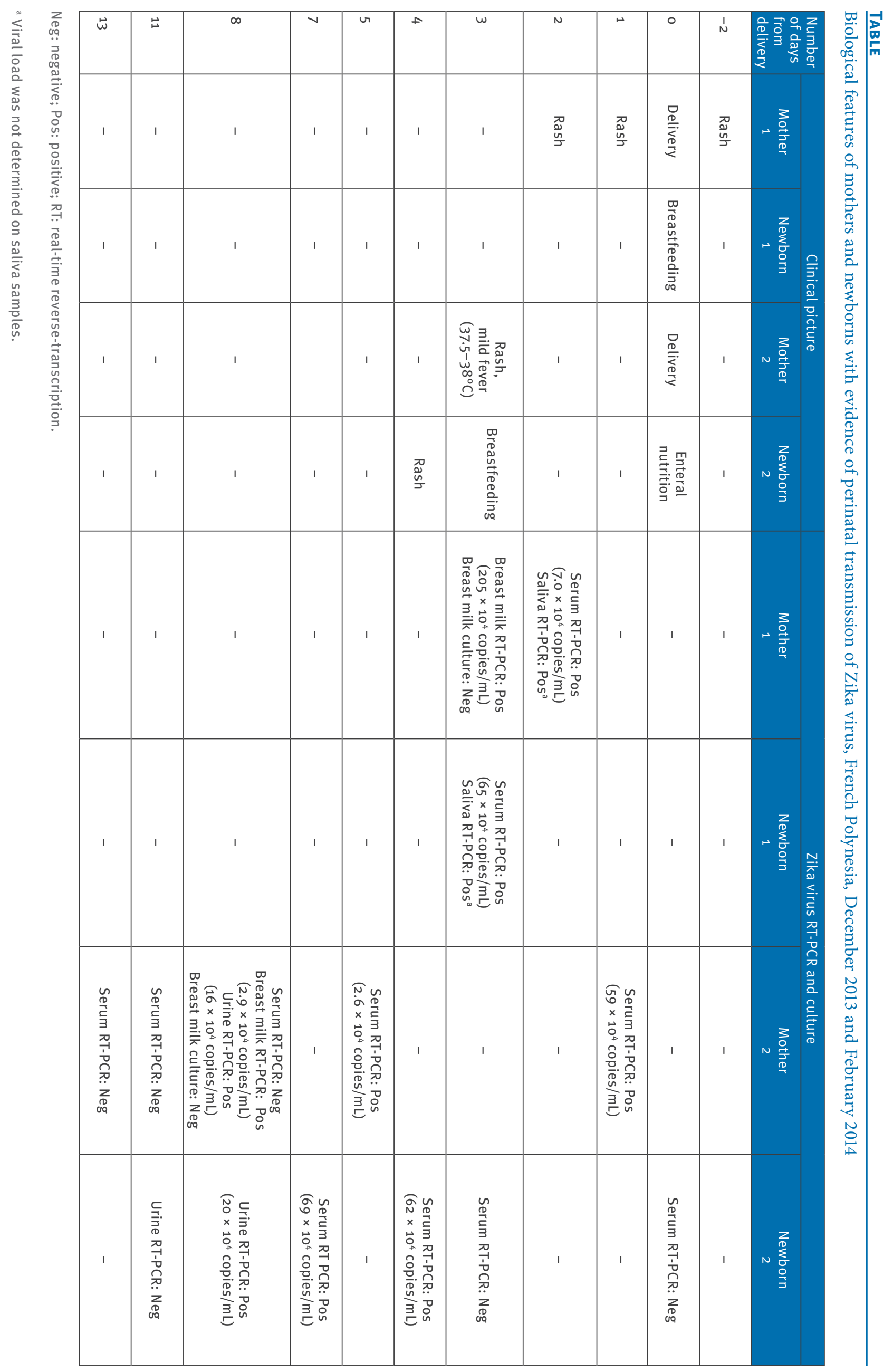


Detailed laboratory results for ZIKAV PCR and culture are reported in the Table.

\section{Ethics approval}

Informed written consent was obtained from the two mothers and publication of data related to ZIKAV infections was approved by the Ethics Committee of French Polynesia (reference 66/CEPF).

\section{Background}

ZIKAV, first isolated in 1947 from a rhesus monkey in Zika Forest, Uganda, is an arthropod-borne virus (arbovirus) belonging to the Flaviviridae family and the Flavivirus genus [6]. Since the 1960s, human cases have been sporadically reported in Asia and Africa [7], but the first large documented outbreak occurred in 2007 in Yap Island, Micronesia, in the North Pacific, where physicians reported an outbreak characterised by rash, conjunctivitis and arthralgia [8].

ZIKAV is transmitted by mosquitoes, especially Aedes species [7]. Direct inter-human transmission, most likely by sexual intercourse, has been described [9]. As little is known about ZIKAV transmission, we investigated other possible modes of transmission. The cases studied provide the first reported evidence of perinatal transmission of ZIKAV.

\section{Discussion}

Perinatal transmission of arbovirus has been reported for DENV [10-14], chikungunya virus (CHIKV) $[15,16]$, West Nile virus (WNV) [17,18] and yellow fever virus (YFV) $[19,20]$. Breast milk transmission has been reported for DENV [14] and WNV [18] and has been suspected for the vaccine strain of YFV [20]. Severe consequences of arbovirus materno-fetal transmission have been reported, notably for CHIKV (encephalopathy and haemorrhagic fever) [16] and DENV (preterm delivery, fetal death, low birth weight, fetal anomalies, prematurity and acute fetal distress during labour) $[10,12]$.

The possible routes of perinatal transmission are transplacental, during delivery, during breastfeeding and by close contact between the mother and her newborn. The sera from the mothers were RT-PCR positive within two days post-delivery and those of their newborns within four days post-delivery. The observation that Mother 1 had displayed a rash two days before delivery and was confirmed ZIKAV RT-PCR positive on two days post-delivery suggests that she was viraemic before and during delivery. Mother 2's serum was RT-PCR positive the day after delivery, suggesting that she was viraemic or at least incubating ZIKAV at the time of delivery. As there are no firm data on the delay necessary for ZIKAV to become detectable by RT-PCR in serum after exposure, the observation that ZIKAV RNA was detectable as early as three and four days postdelivery in the newborns does not provide evidence of transplacental transmission rather than contamination during delivery. Evidence of transplacental transmission would have been the delivery of a viraemic newborn, but the serum sample collected the day of delivery from Newborn 2 was RT-PCR negative; no sample was available on the delivery day for Newborn 1.

In November 2013, a first case of perinatal transfusion of ZIKAV was suspected in French Polynesia: the newborn displayed a maculopapular rash at delivery and the mother reported a ZIKAV infection-like syndrome two weeks before (data not shown). Unfortunately, however, virological investigations were not performed.

The detection of ZIKAV RNA by PCR in breast milk samples in our study raises the question of possible transmission by breastfeeding. The fact that replicative ZIKAV was not found in breast milk samples makes contamination by this route unlikely. The finding that RT-PCR on Newborn 2's serum was positive the day following the start of breast feeding can reasonably exclude this route of contamination for this infant. The ZIKV RNA load reported in the two breast milk samples $\left(2.9 \times 10^{4}\right.$ and $205 \times 10^{4}$ copies $\left./ \mathrm{mL}\right)$ were higher than the DENV RNA load reported in a suspected case of DENV breast milk transmission (>0.01 × $10^{4}$ and >0.1 $\times$ $10^{4}$ copies $/ \mathrm{mL}$ ) in New Caledonia in 2012 [14]. Of interest, CHIKV RNA was not detected from 20 milk samples collected from breastfeeding viraemic mothers during an outbreak of CHIKV infection in Réunion Island in 2005-06 [16].

As saliva samples from Mother 1 and Newborn 1 gave positive RT-PCR results, contamination by close contact cannot be excluded. However, it is currently unknown whether saliva actually contains replicative ZIKV.

Contamination of the newborns as a result of being bitten by an infected mosquito bite seems fairly improbable because of the air-conditioned rooms in the hospital.

Even though the newborns had similar ZIKAV RNA loads (about $60 \times 10^{4}$ copies $/ \mathrm{mL}$ ) in serum, Newborn 1 remained asymptomatic, whereas Newborn 2 displayed a maculopapular rash and thrombocytopenia. This newborn also had low birth weight but we do not have data to suggest this was due to ZIKAV infection, especially as there was intrauterine growth restriction from the second trimester of pregnancy and gestational diabetes.

During this large outbreak, many pregnant women could have been infected by ZIKAV, but we did not register any increase in the number of fetal deaths or premature births.

\section{Conclusions}

Given the severe neonatal diseases reported with other arbovirus infections, such as chikungunya [16] and dengue $[10,12]$, we recommend close monitoring of perinatal ZIKAV infections. Due to the high ZIKAV RNA load detected in breast milk, and even though no replicative 
ZIKAV particles were detected, ZIKAV transmission by breastfeeding must be considered.

Zika fever has been reported in tourists returning from French Polynesia to Japan in 2013-14 [21]. An outbreak of ZIKAV infection was also declared in February 2014 in New Caledonia, in the South Pacific [22]. Patients living in or returning from ZIKAV-endemic or epidemic areas presenting with a 'dengue-like' syndrome but testing negative for DENV should be tested for ZIKAV, with attention paid to infected pregnant women and their newborns, as data on the impact of the infection on them are limited.

\section{Acknowledgements}

We acknowledge Ms Claudine Roche for helpful technical support.

\section{Conflict of interest}

None declared.

\section{Author's contributions}

MB, SL, VM CL and DM wrote the manuscript. AT performed laboratory investigations.

\section{References}

1. Cao-Lormeau VM, Roche C, Teissier A, Robin E, Berry AL, Mallet HP, et al. Zika virus, French Polynesia, South Pacific. 2013. Emerg Infect Dis. Forthcoming 2014.

2. European Centre for Disease prevention and Control (ECDC). Zika virus infection outbreak, French Polynesia. 14 February 2014. Stockholm: ECDC; 2014. Available from: http://www. ecdc.europa.eu/en/publications/Publications/Zika-virusFrench-Polynesia-rapid-risk-assessment.pdf

3. Cao-Lormeau VM, Roche C, Musso D, Mallet HP, Dalipana T, Dofai A, et al. Dengue virus type-3, South Pacific Islands, 2013. Emerg Infect Dis. Forthcoming 2014.

4. Lanciotti RS, Kosoy OL, Laven JJ, Velez JO, Lambert AJ, Johnson AJ, et al. Genetic and serologic properties of Zika virus associated with an epidemic, Yap State, Micronesia, 2007. Emerg Infect Dis. 2008;14(8):1232-9. http://dx.doi. org/10.3201/eid1408.080287

5. Johnson BW, Russell BJ, Lanciotti RS. Serotype-specific detection of dengue viruses in a fourplex real-time reverse transcriptase PCR assay. J Clin Microbiol. 2005;43(10):4977-83. http://dx.doi.org/10.1128/JCM.43.10.4977-4983.2005

6. Kirya BG. A yellow fever epizootic in Zika Forest, Uganda, during 1972: Part 1: Virus isolation and sentinel monkeys. Trans R Soc Trop Med Hyg. 1977;71(3):254-6o. http://dx.doi. org/10.1016/0035-9203(77)90020-7

7. Hayes EB. Zika virus outside Africa. Emerg Infect Dis. 2009;15(9):1347-50. http://dx.doi.org/10.3201/eid1509.090442

8. Duffy MR, Chen TH, Hancock WT, Powers AM, Kool JL, Lanciotti RS, et al. Zika virus outbreak on Yap Island, Federated States of Micronesia. N Engl J Med. 2009;36o(24):2536-43. http:// dx.doi.org/10.1056/NEJMoa0805715

9. Foy BD, Kobylinski KC, Chilson Foy JL, Blitvich BJ, Travassos da Rosa A, Haddow AD, et al. Probable non-vector-borne transmission of Zika virus, Colorado, USA. Emerg Infect Dis. 2011;17(15):880-2. http://dx.doi.org/10.3201/eid1705.101939

10. Tan PC, Rajasingam G, Devi S, Omar SZ. Dengue infection in pregnancy: prevalence, vertical transmission, and pregnancy outcome. Obstet Gynecol. 2008;111(5):1111-7. http://dx.doi. org/10.1097/AOG.obo13e31816a49fc

11. Pouliot SH, Xiong X, Harville E, Paz-Soldan V, Tomashek KM, Breart G, et al. Maternal dengue and pregnancy outcomes : a systematic review. Obstet Gynecol Surv. 2010;65(2):107-18.
12. Basurko C, Carles G, Youssef M, Guindi WE. Maternal and foetal consequences of dengue fever during pregnancy. Eur I Obstet Gynecol Reprod Biol. 2009;147(1):29-32. http://dx.doi. org/10.1016/j.ejogrb.2009.06.028

13. Adam I, Jumaa AM, Elbashir HM, Karsany MS. Maternal and perinatal outcomes of dengue in PortSudan, Eastern Sudan. Virol J. 2010;7:153. http://dx.doi.org/10.1186/1743-422X-7-153

14. Barthel A, Gourinat AC, Cazorla C, Joubert C, Dupont-Rouzeyrol $M$, Descloux E. Breast milk as a possible route of vertical transmission of dengue virus? Clin Infect Dis. 2013;57(3):415-7. http://dx.doi.org/10.1093/cid/cit227

15. Fritel X, Rollot O, Gerardin P, Gauzere BA, Bideault J, Lagarde L, et al. Chikungunya virus infection during pregnancy, Reunion, France, 2006. Emerg Infect Dis. 2010;16(3):418-25. http:// dx.doi.org/10.3201/eid1604.091403

16. Gérardin P, Barau G, Michault A, Bintner M, Randrianaivo H, Choker G, et al. Multidisciplinary prospective study of motherto-child chikungunya virus infections on the island of $\mathrm{La}$ Réunion. PLoS Med. 2008;5(3):e60. http://dx.doi.org/10.1371/ journal.pmed.0050060

17. Stewart RD, Bryant SN, Sheffield JS. West nile virus infection in pregnancy. Case Rep Infect Dis. 2013;2013:351872.

18. Center for Disease Control and prevention. Possible West Nile virus transmission to an infant through breast-feedingMichigan, 2002. Morb Mortal Wkly Rep. 2002;51(39):877-8.

19. Bentlin MR, de Barros Almeida RA, Coelho KI, Ribeiro AF, Siciliano MM, Suzuki A, et al. Perinatal transmission of yellow fever, Brazil, 2009. Emerg Infect Dis. 2011;17(9):1779-80. http://dx.doi.org/10.3201/eid1709.110242

20. Kuhn S, Twele-Montecinos L, MacDonald J, Webster P, Law B. Case report: probable transmission of vaccine strain of yellow fever virus to an infant via breast milk. CMAJ. 2011;183(4):E243-5. http://dx.doi.org/10.1503/cmaj.100619

21. Kutsuna S, Kato Y, Takasaki T, Moi M, Kotaki A, Uema H, et al. Two cases of Zika fever imported from French Polynesia to Japan, December 2013 to January 2014. Euro Surveill. 2014;19(4):pii:20683.

22. Direction des Affaires Sanitaires et Sociales de Nouvelle Caledonie (DASS-NC). Epidemie de Zika. [Zika epidemic]. Nouméa : DASS-NC; 27 Mar 2014. French. Available from: http://www.dass.gouv.nc/portal/page/portal/dass/alertes 